\title{
Glomerular type 1 angiotensin receptors augment kidney injury and inflammation in murine autoimmune nephritis
}

\author{
Steven D. Crowley, ${ }^{1}$ Matthew P. Vasievich, ${ }^{1}$ Phillip Ruiz, ${ }^{2}$ Samantha K. Gould, ${ }^{1}$ Kelly K. Parsons, ${ }^{1}$ \\ A. Kathy Pazmino, ${ }^{1}$ Carie Facemire, ${ }^{1}$ Benny J. Chen, ${ }^{3}$ Hyung-Suk Kim, ${ }^{4}$ Trinh T. Tran, ${ }^{5}$ \\ David S. Pisetsky, ${ }^{5}$ Laura Barisoni, ${ }^{6}$ Minolfa C. Prieto-Carrasquero, ${ }^{7}$ Marie Jeansson, ${ }^{8}$ \\ Mary H. Foster, ${ }^{1}$ and Thomas M. Coffman ${ }^{1}$

\begin{abstract}
1Department of Medicine, Division of Nephrology, Duke University Medical Center, and Durham VA Medical Center, Durham, North Carolina, USA. 2Department of Pathology, Leonard M. Miller School of Medicine, University of Miami, Miami, Florida, USA. ${ }^{3}$ Department of Medicine, Division of Cellular Therapy, Adult Bone Marrow and Stem Cell Transplant Program, Duke University Medical Center, Durham, North Carolina, USA. ${ }^{4}$ Department of Pathology, University of North Carolina, Chapel Hill, North Carolina, USA. 5Department of Medicine, Division of Rheumatology, Duke University Medical Center, and Durham VA Medical Center, Durham, North Carolina, USA. ${ }^{6}$ Department of Pathology, New York University School of Medicine, New York, New York, USA. ${ }^{7}$ Department of Physiology and Hypertension and Renal Center of Excellence, Tulane University Health Sciences Center, New Orleans, Louisiana, USA. ${ }^{8}$ Samuel Lunenfeld Research Institute, University of Toronto, Toronto, Ontario, Canada.
\end{abstract}

\begin{abstract}
Studies in humans and animal models indicate a key contribution of angiotensin II to the pathogenesis of glomerular diseases. To examine the role of type 1 angiotensin $\left(\mathrm{AT}_{1}\right)$ receptors in glomerular inflammation associated with autoimmune disease, we generated MRL-Fas $l p r / p r(l p r)$ mice lacking the major murine type 1 angiotensin receptor $\left(\mathrm{AT}_{1 \mathrm{~A}}\right)$; $l p r$ mice develop a generalized autoimmune disease with glomerulonephritis that resembles SLE. Surprisingly, $\mathrm{AT}_{1 \mathrm{~A}}$ deficiency was not protective against disease but instead substantially accelerated mortality, proteinuria, and kidney pathology. Increased disease severity was not a direct effect of immune cells, since transplantation of $\mathrm{AT}_{1 \mathrm{~A}}$-deficient bone marrow did not affect survival. Moreover, autoimmune injury in extrarenal tissues, including skin, heart, and joints, was unaffected by $\mathrm{AT}_{1 \mathrm{~A}} \mathrm{deficiency.} \mathrm{In}$ murine systems, there is a second type 1 angiotensin receptor isoform, $\mathrm{AT}_{1 \mathrm{~B}}$, and its expression is especially prominent in the renal glomerulus within podocytes. Further, expression of renin was enhanced in kidneys of $\mathrm{AT}_{1 \mathrm{~A}}$-deficient $l p r$ mice, and they showed evidence of exaggerated $\mathrm{AT}_{1 \mathrm{~B}}$ receptor activation, including substantially increased podocyte injury and expression of inflammatory mediators. Administration of losartan, which blocks all type 1 angiotensin receptors, reduced markers of kidney disease, including proteinuria, glomerular pathology, and cytokine mRNA expression. Since $\mathrm{AT}_{1 \mathrm{~A}}$-deficient $l p r$ mice had low blood pressure, these findings suggest that activation of type 1 angiotensin receptors in the glomerulus is sufficient to accelerate renal injury and inflammation in the absence of hypertension.
\end{abstract}

\section{Introduction}

The renin-angiotensin system (RAS) has profound effects on blood pressure and vascular reactivity (1). Angiotensin II, acting through type 1 angiotensin $\left(\mathrm{AT}_{1}\right)$ receptors, contributes to the pathophysiology of diverse disorders from progressive renal disease to cardiac hypertrophy to atherosclerosis (2-4). In addition, recent studies have suggested that $\mathrm{AT}_{1}$ receptors may contribute to disease pathogenesis through direct effects on cellular immune responses and inflammation. For example, angiotensin II triggers $\mathrm{T}$ lymphocyte proliferation through a calcineurindependent pathway during the alloimmune response (5). Furthermore, blockade of the $\mathrm{AT}_{1}$ receptor or targeted deletion of the dominant murine $\mathrm{AT}_{1}$ receptor isoform, $\mathrm{AT}_{1 \mathrm{~A}}$, prolongs allograft survival in rodent models $(4,5)$. In contrast, actions of $\mathrm{AT}_{1}$ recep-

Conflict of interest: The authors have declared that no conflict of interest exists.

Nonstandard abbreviations used: $\mathrm{ACE}$, angiotensin-converting enzyme; $\mathrm{AT}_{1}$, type 1 angiotensin (receptor); BUN, blood urea nitrogen; CFP, cyan fluorescent protein; JGA, juxtaglomerular apparatus; $l p r, M R L$-Fas ${ }^{l p r / l p r} ; l p r$-KO, MRL-Fas ${ }^{l p r / p r}$ Agtr1a $1 a^{-/-}$; MCP-1, monocyte chemoattractant protein-1; RAS, renin-angiotensin system; ssDNA, singlestranded DNA; TCA-3, T cell activation gene-3.

Citation for this article: J. Clin. Invest. 119:943-953 (2009). doi:10.1172/JCI34862. tors may have protective effects in other disorders. For instance, in a model of obstructive uropathy, the absence of $\mathrm{AT}_{1}$ receptors on hematopoietic cells is associated with enhanced levels of renal fibrosis (6). While most of the actions of angiotensin II to promote inflammation and tissue injury are mediated by the $\mathrm{AT}_{1}$ receptor, activation of $\mathrm{AT}_{2}$ receptors has been linked to enhanced chemokine expression in the kidney (7).

In autoimmune glomerulonephritis, previous studies suggest that blockade of the RAS has beneficial effects. MRL/MpJ-Fas ${ }^{p r} / p r$ (lpr) mice develop florid autoimmune disease resembling human SLE including autoantibodies, arthritis, and proliferative glomerulonephritis $(8,9)$. Treatment of $l p r$ mice with angiotensin-converting enzyme (ACE) inhibitors or $\mathrm{AT}_{1}$ receptor blockers reduces glomerular injury and albuminuria $(10,11)$. Together, these data suggest that angiotensin II may contribute to the pathogenesis of autoimmune nephritis. In humans with SLE, the contribution of the RAS to the development of renal disease is less clear. Although lower serum ACE levels have been associated with reduced severity of renal disease in some studies $(12,13)$, this has not been a universal finding (14). Case series suggest a benefit of ACE inhibition in patients with established lupus nephritis (15). However, there are 


\section{Table 1}

Lymphoid organ parameters in Iprand Ipr-K0 mice at 12 weeks of age

\begin{tabular}{|c|c|c|c|c|}
\hline & & $\begin{array}{l}\text { Left axillary } \\
\text { lymph node }\end{array}$ & Spleen & Thymus \\
\hline \multirow[t]{2}{*}{ Weight (g) } & $I p r$ & $47 \pm 12$ & $196 \pm 19$ & $94 \pm 6$ \\
\hline & Ipr-KO & $52 \pm 12$ & $188 \pm 22$ & $103 \pm 10$ \\
\hline \multirow[t]{2}{*}{$\mathrm{CD}^{+} \mathrm{B}^{220}+$ cells (\%) } & $I p r$ & $56.3 \pm 2.8$ & $28.2 \pm 2.6$ & $15.4 \pm 3.5$ \\
\hline & Ipr-KO & $54.0 \pm 3.4$ & $26.1 \pm 2.9$ & $7.8 \pm 2.9$ \\
\hline \multirow[t]{2}{*}{ CD4+ CD25+ cells (\%) } & $l p r$ & $2.0 \pm 0.2$ & $4.5 \pm 0.7$ & $5.5 \pm 0.8$ \\
\hline & $\mathrm{Ipr}-\mathrm{KO}$ & $2.3 \pm 0.4$ & $4.1 \pm 0.2$ & $5.5 \pm 0.6$ \\
\hline
\end{tabular}

no randomized trials of ACE inhibitors or angiotensin receptor blockade in patients with lupus nephritis.

Thus, previous studies suggest a role for the RAS in regulating inflammatory responses, but its role is complex. Accordingly, the objective of the present studies was to use a genetic approach to investigate the role of $\mathrm{AT}_{1}$ receptors in the development of autoimmune disease. To this end, we generated an $l p r$ mouse line deficient in the major murine $\mathrm{AT}_{1}$ receptor, $\mathrm{AT}_{1 \mathrm{~A}}$, and characterized its clinical features. Surprisingly, we found enhanced mortality and more aggressive kidney disease in $l p r$ mice lacking $\mathrm{AT}_{1 \mathrm{~A}}$ receptors. This acceleration of renal disease is caused by activation of glomerular $\mathrm{AT}_{1 \mathrm{~B}}$ receptors. These experiments therefore demonstrate for what we believe is the first time that activation of $\mathrm{AT}_{1}$ receptors in the glomerulus can directly promote inflammatory injury in the kidney independent of elevated blood pressure.

\section{Results}

Accelerated mortality in MRL-Fas ${ }^{l p r / p r}$ mice lacking $A T_{1 A}$ receptors. To examine the role of $\mathrm{AT}_{1}$ receptors in modulating autoimmune disease, we generated MRL-Fas ${ }^{l p r / p r} A g t r 1 a^{-/-}(l p r-\mathrm{KO})$ mice lacking

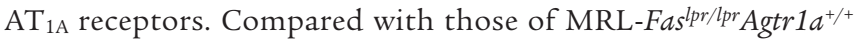
(lpr) controls, average weights for lymph nodes, spleen, or thymus were very similar at 12 weeks of age. In addition, the absence of $\mathrm{AT}_{1 \mathrm{~A}}$ receptors did not significantly affect the cell-surface phenotypes of crucial cells in these lymphoid organs (Table 1), including the population of the double-negative $\mathrm{CD} 4^{-} \mathrm{CD} 8^{-} \mathrm{CD} 3^{+} \mathrm{B} 220^{+}$ cells, which are characteristic of lpr mice. However, as shown in Figure 1, survival was significantly reduced in the $l p r$-KO animals compared with the lpr group. The mean duration of survival was $117 \pm 4$ days in the $l p r-\mathrm{KO}$ group compared with $162 \pm 11$ days in the lpr group $(P=0.001)$. Also, blood pressure levels in $l p r-\mathrm{KO}$ mice $(129 \pm 2 \mathrm{mmHg})$ were modestly but significantly lower than those of the lpr controls $(137 \pm 2 \mathrm{mmHg} ; P=0.001)$.

Urinary albumin excretion is increased in $l p r$ mice lacking $\mathrm{AT}_{1 \mathrm{~A}}$ receptors. Kidney disease is the major cause of death in lpr mice. Similarly to the situation with patients with lupus nephritis, proteinuria is a useful index of renal disease activity in $l p r$ mice. Therefore, we compared urinary albumin excretion in $l p r$ and $l p r-\mathrm{KO}$ mice at 12 weeks of age, a time point in the disease before there is appreciable mortality in either group. As shown in Figure 2, urinary albumin excretion was significantly higher in the $l p r$-KO mice $(77 \pm 14 \mu \mathrm{g} / 24 \mathrm{~h})$ than in $l p r$ controls $(39 \pm 4 \mu \mathrm{g} / 24 \mathrm{~h} ; P<0.02)$.

Absence of $A T_{1 A}$ receptors increases the severity of kidney structural injury in lpr mice. To determine whether the increased albuminuria in lpr-KO mice is associated with enhanced renal injury, kidneys were systematically examined for the presence of pathological changes in the glomerular, vascular, and interstitial compartments. As shown in Table 2, the severity of renal pathological abnormalities was significantly increased in lpr-KO animals compared with $l p r$ controls $(P=0.001)$. Typical of MRL-Fas ${ }^{l p r} / p r$ mice at this age, glomerular lesions in the 12-week-old lpr group were relatively mild (Figure 3A and Table 2) (16). In contrast, kidneys from $l p r$-KO mice showed severe pathological findings in glomeruli including hypercellularity, focal necrosis, mesangial expansion, and glomerulosclerosis (Figure 3B and Table 2). While the interstitial regions of kidneys from $l p r$ mice contained very few inflammatory cells (Figure $3 \mathrm{C}$ and Table 2), mononuclear cell infiltrates focused primarily around the vasculature were prominent in kidneys from $l p r-\mathrm{KO}$ animals (Figure 3D and Table 2). Finally, whereas vascular structures were largely preserved in kidneys from lpr controls, abnormal vascular architecture was commonly observed in the lpr-KO mice characterized by sclerosis and/or stenosis of arteries and arterioles (Figure 3, E-G). To determine whether enhanced renal pathology was associated with alterations in kidney function, we measured blood urea nitrogen (BUN) levels in 16-week-old lpr and lpr-KO groups. By this time point, a number of the more severely affected lpr-KO animals had succumbed. Nonetheless, BUN levels (54 \pm 7 $\mathrm{mg} / \mathrm{dl})$ were still significantly higher in $l p r-\mathrm{KO}$ mice than in $l p r$ controls $(40 \pm 4 \mathrm{mg} / \mathrm{dl})(P=0.03)$.

Expression of inflammatory mediator genes is increased in kidneys of $l p r$ mice lacking $A T_{1 A}$ receptors. We used the RNAse protection assay to measure mRNA levels of a panel of pertinent inflammatory mediators in the kidney. Typically, there is minimal expression of these mediators in kidneys of normal mice (17). As shown in Figure 4, A-D, expression of mRNAs for several cytokines and chemokines was detected in kidneys from $l p r$ controls. Expression of a number of these mRNAs, including IFN- $\gamma$, RANTES, monocyte chemoattractant protein-1 (MCP-1), and T cell activation gene-3 (TCA-3), was significantly augmented in kidneys from the $\mathrm{p} r$-KO animals.

In human patients with lupus nephritis, TGF- $\beta$ RNA levels in the urinary sediment correlate with disease activity (18). Moreover, several lines of evidence indicate that angiotensin II may promote progression of chronic kidney disease by stimulating production of TGF- $\beta(19,20)$. Surprisingly, as demonstrated in Figure 4, E and F, TGF- $\beta$ mRNA expression was significantly increased in kidneys of $l p r$-KO mice compared with those of $l p r$ controls $(P=0.02)$.

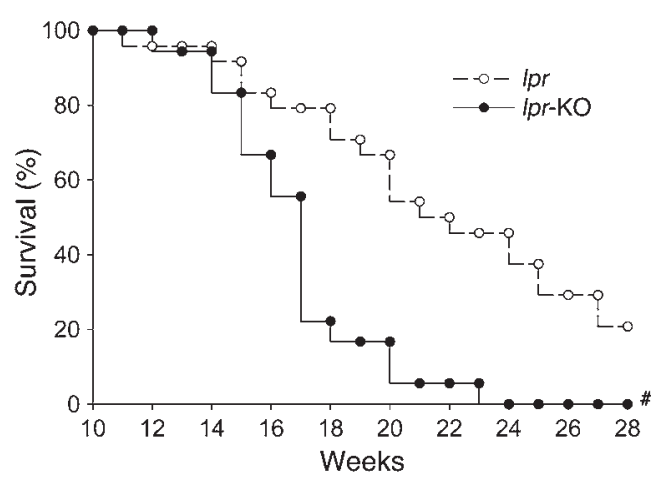

\section{Figure 1}

Reduced survival in $/ p r$ mice lacking $\mathrm{AT}_{1 \mathrm{~A}}$ receptors. \#The mean duration of survival was significantly reduced in Ipr-KO mice (117 \pm 4 days) compared with $/ p r$ controls $(162 \pm 11$ days; $P=0.001) . n=24$ for $/ p r(10$ males and 14 females) group; $n=18 \mathrm{Ipr}$-KO group ( 8 males and 10 females). 


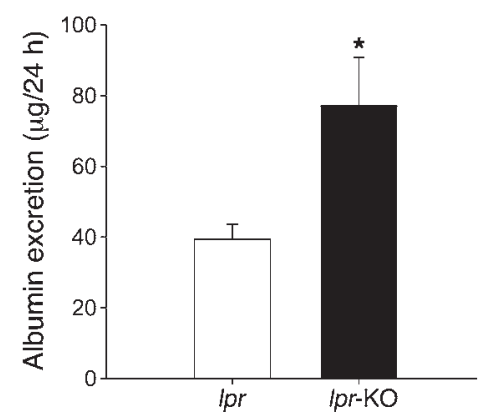

\section{Figure 2}

Elimination of $\mathrm{AT}_{1 \mathrm{~A}}$ receptors augments albuminuria in MRL-Fas $/ p r / / p r$ mice. At 12 weeks of age, 24-hour urinary albumin excretion was significantly higher in Ipr-KO mice $(77 \pm 14 \mu \mathrm{g} / 24 \mathrm{~h})$ than in Ipr controls $\left(39 \pm 4 \mu \mathrm{g} / 24 \mathrm{~h} ;{ }^{*} P<0.02\right) . n=18$ for $/ p r$ group (9 males and 9 females); $n=21$ for $/ p r-K O$ group (11 males and 10 females).

Autoimmune injury in extrarenal tissues is not enhanced in lpr-KO mice. Autoimmune disease in MRL-Fas ${ }^{p r / p r}$ mice affects multiple organ systems in addition to the kidney (8). To determine whether elimination of $\mathrm{AT}_{1 \mathrm{~A}}$ receptors affected the severity of autoimmune damage in other systems, we also assessed the extent of pathological injury in extrarenal tissues including hearts, joints, and skin from 12-week-old mice. There were minimal and equivalent pathological changes in hearts from $l p r$ and $l p r-K O$ mice (data not shown). Similarly, by 12 weeks of age, none of the mice had developed clinically apparent autoimmune skin lesions. To characterize the severity of arthritis, knees were harvested, decalcified, fixed, stained, and systematically scored for fibrosis and mononuclear cell infiltrates as previously described (21). Both groups demonstrated a low level of inflammation in the joint, but the degree of injury was not different between the $l p r$ and $l p r$-KO groups $(2.4 \pm 0.6$ vs. $1.3 \pm 0.3 \mathrm{AU}$; $P=\mathrm{NS})$. Thus, at 12 weeks of age, when we noted a marked exaggeration of kidney pathology in lpr-KO mice compared with $l p r$ controls, only minimal and equivalent levels of pathology could be detected in extrarenal tissues commonly affected in this model.

Another feature of the lpr lymphoproliferative phenotype is the development of circulating autoantibodies. However, as shown in Figure 5, the experimental groups had similar levels of anti-singlestranded DNA (anti-ssDNA) and anti-dsDNA activity.

Accelerated renal disease in $A T_{1 A}$ receptor-deficient lpr mice is not due to differences in blood pressure. To determine whether the differences in blood pressure levels contributed to the discrepant severity of kidney disease between $l p r$ and $l p r-\mathrm{KO}$ mice, we treated groups of $l p r$ mice with hydralazine $(37 \mathrm{mg} / \mathrm{kg} / \mathrm{d})$ starting after 4 weeks of age. Blood pressure levels in the lpr group treated with hydralazine $(n=12)$ were significantly lower than in untreated $l$ pr controls ( $132 \pm 2$ vs. $137 \pm 2$ $\mathrm{mmHg} ; P<0.04)$ and not different from those of $l p r$-KO animals $(132 \pm 2$ vs. $129 \pm 2 \mathrm{mmHg} ; P=\mathrm{NS})$. Mean survival of $l p r$ mice treated with hydralazine was significantly greater than that of the $l p r$-KO group (165 \pm 12 vs. $117 \pm 4$ days; $P=0.001)$ and was similar to that of the lpr control group (162 \pm 11 days; $P=\mathrm{NS}$ ). Likewise, urinary albumin excretion $(46 \pm 5 \mu \mathrm{g} / 24 \mathrm{~h})$ and the extent of renal pathology in the $l p r$ group treated with hydralazine were comparable to that of $l p r$ controls ( $8.3 \pm 1.9 \mathrm{AU} ; P=\mathrm{NS})$ and substantially attenuated compared with that of $l p r-\mathrm{KO}$ mice $(13.1 \pm 1.0 ; P=0.06)$.

Transplantation with bone marrow from $A T_{1 A}$ receptor-deficient donors does not affect survival of lpr mice. The transfer of normal MRL-MpJ bone marrow into MRL-Fas ${ }^{l p r / p r}$ mice attenuates autoimmune disease in the bone marrow recipients $(22,23)$, confirming a primary role for immune dysregulation in the pathogenesis of $l p r$ disease. To determine whether the accelerated disease in the lpr-KO mice is due to direct consequences of $\mathrm{AT}_{1 \mathrm{~A}}$ receptor deficiency on immune cell function, we transplanted bone marrow from $l p r$-KO (MRL-Fas ${ }^{l p r / p r}$ Agtr1 $1 a^{-/-}$) or $\operatorname{lpr}$ (MRL-Fas ${ }^{l p r / l p r} A g t r 1 a^{+/+}$) donors into irradiated $l p r$ (MRL-Fas $\left.{ }^{p r / p r} A g t r 1 a^{+/+}\right)$recipients. With this strategy, we compared outcome in $l p r$ bone marrow chimeras, lacking $\mathrm{AT}_{1 \mathrm{~A}}$ receptors only in cell lineages derived from bone marrow, to that of $l p r$ controls with normal expression of $\mathrm{AT}_{1 \mathrm{~A}}$ receptors in all tissues.

Using Southern blot analysis, we confirmed that the extent of engraftment with $\mathrm{AT}_{1 \mathrm{~A}}$ receptor-deficient bone marrow was more than $98 \%$ (Figure 6A). Survival of $l p r$ mice transplanted with bone marrow from $l p r$ donors $(230 \pm 11$ days) was significantly prolonged compared with that of nontransplanted nonirradiated $l p r$ controls (162 \pm 11 days; $P<0.0001)$. However, as shown in Figure $6 \mathrm{~B}$, this was virtually identical to the mean survival of $l p r$ animals transplanted with $l p r$-KO bone marrow lacking $\mathrm{AT}_{1 \mathrm{~A}}$ receptors $\left(234 \pm 8\right.$ days; $P=\mathrm{NS}$ ) (Figure 6B). Thus, the absence of $\mathrm{AT}_{1 \mathrm{~A}}$ receptors on immune cell lineages derived from bone marrow does not account for the accelerated mortality in lpr-KO mice.

Renin expression is enhanced in lpr mice lacking $A T_{1 A}$ receptors. Because the absence of $\mathrm{AT}_{1 \mathrm{~A}}$ receptors from bone marrow-derived cells does not appear to explain the accelerated disease in $l p r-\mathrm{KO}$ mice, we considered the possibility that systemic consequences of $\mathrm{AT}_{1 \mathrm{~A}}$ receptor deficiency might play a role. On other genetic backgrounds, the absence of $\mathrm{AT}_{1 \mathrm{~A}}$ receptors is associated with enhanced renin expression and hypertrophy of the juxtaglomerular apparatus (JGA), presumably due to the absence of short-loop feedback inhibition of renin mediated by $\mathrm{AT}_{1}$ receptors $(24,25)$. As generation of renin is a key rate-limiting step determining the activity of the RAS, the increase in renin in $\mathrm{AT}_{1 \mathrm{~A}}$ receptor-deficient mice leads to increases in circulating levels of angiotensin II (26). To assess the extent of RAS activity, we compared renin mRNA expression in kidneys of $l p r$ and $l p r-\mathrm{KO}$ mice at 12 weeks of age. Renin mRNA levels were increased more than 3-fold in kidneys from $l p r$-KO mice compared with those of $l p r$ controls (333 \pm 56 vs. $100 \pm 17 \mathrm{AU} ; P=0.001)$. To confirm that the increase in renin mRNA levels was accompanied by an increase in renin protein, we performed immunostaining for renin in sections of renal cortex ( $n \geq 12$ mice per group; >300 glomeruli scored per group). Using standard methods (27) and as illustrated in Figure 7, the number of glomeruli with detectable staining for renin protein in the JGA was significantly higher in the $\mathrm{p} r$-KO mice (127 out of 419 glomeruli: $30.3 \%$ ) than in controls (59 out of 328 glomeruli: $18.0 \%$; $P<0.0001$ by $\left.\chi^{2}\right)$. In contrast, aldosterone levels in the blood were similar in the lpr and $l p r-\mathrm{KO}$ groups $(327 \pm 87$ vs. $370 \pm 24 \mathrm{pg} / \mathrm{ml}$;

\section{Table 2}

Histopathologic injury scores for kidneys from Iprand Ipr-KO mice at 12 weeks of age

\begin{tabular}{llccc} 
Group & Glomeruli & Interstitium & Vascular damage & Total \\
Ipr & $5.6 \pm 0.9$ & $0.6 \pm 0.1$ & $2.4 \pm 0.3$ & $8.0 \pm 1.1$ \\
Ipr-KO & $7.8 \pm 0.7^{\mathrm{A}}$ & $1.3 \pm 0.1^{\mathrm{B}}$ & $5.3 \pm 0.4^{\mathrm{C}}$ & $13.1 \pm 1.0^{\mathrm{D}}$ \\
\hline
\end{tabular}

${ }^{\mathrm{A} P}=0.05 ; \mathrm{B} P=0.0002 ; \mathrm{C} P=0.0001 ;{ }^{\mathrm{D}} P=0.001 \mathrm{vs}$. $/ \mathrm{pr} . \quad n=19 \mathrm{lp} r$ mice (9 males and 10 females) and 24 Ipr-KO mice (14 males and 10 females). 

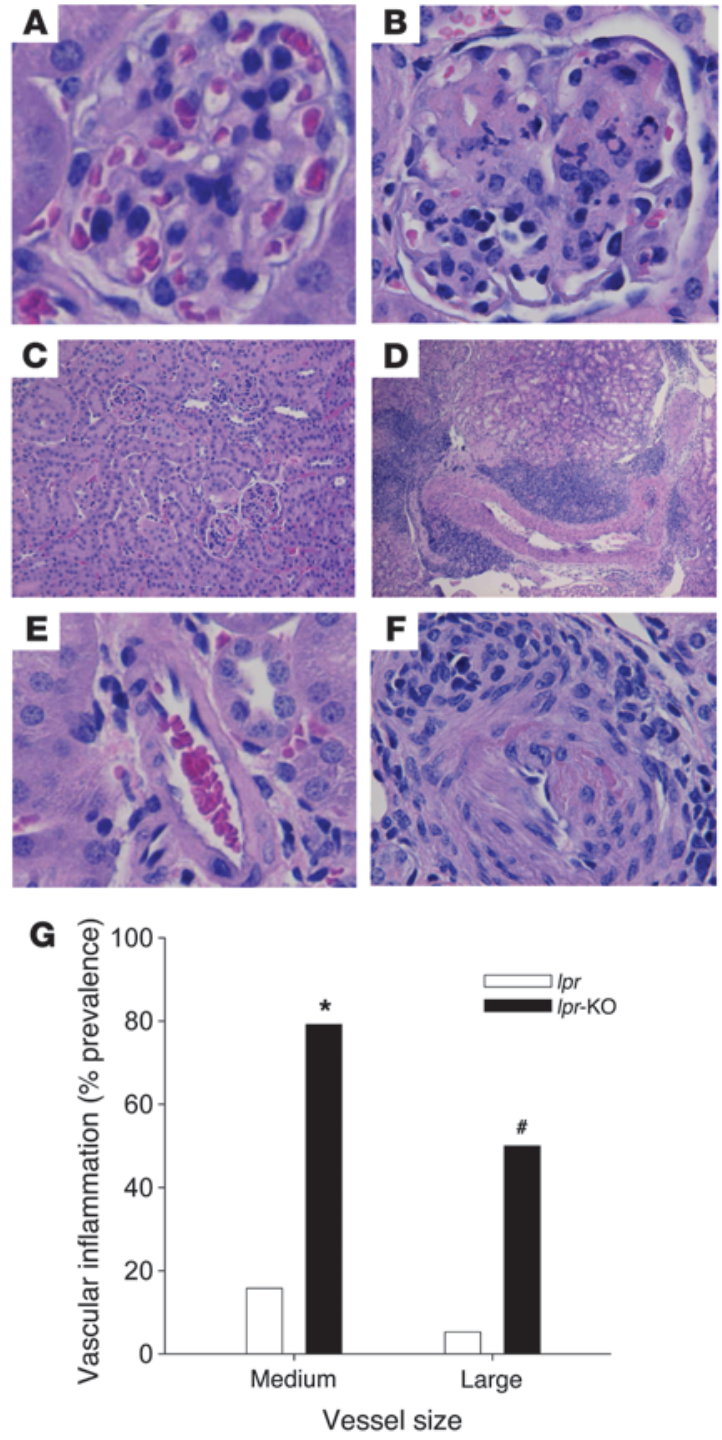

$P=$ NS), consistent with previous reports in nonautoimmune mouse strains showing that $\mathrm{AT}_{1 \mathrm{~A}}$ receptor deficiency did not alter basal aldosterone levels $(28,29)$.

Activation of glomerular $A T_{1}$ receptors accelerates renal disease in lpr-KO mice. In view of the elevated renin levels in $l p r-\mathrm{KO}$ mice, we considered the possibility that systemic activation of the RAS through receptors other than $\mathrm{AT}_{1 \mathrm{~A}}$ might be driving more severe renal disease and enhanced mortality in these animals. Such effects might be mediated by the second $\mathrm{AT}_{1}$ receptor isoform, $\mathrm{AT}_{1 \mathrm{~B}}$, which is fully expressed in $\mathrm{AT}_{1 \mathrm{~A}}$ receptor-deficient mice (30). Previous studies have suggested that within the kidney, the $\mathrm{AT}_{1 \mathrm{~B}}$ receptor is primarily expressed in the glomerulus (30-32), so that activation of glomerular $\mathrm{AT}_{1 \mathrm{~B}}$ receptors could potentially have an impact on glomerular damage and proteinuria in our model. Therefore, to confirm expression of the $\mathrm{AT}_{1 \mathrm{~B}}$ receptor in the kidney in our own experiments, we quantitated renal expression for Agtr $1 b$ using real-time PCR. Modest levels of $\mathrm{AT}_{1 \mathrm{~B}} \mathrm{mRNA}$ expression could be detected in RNA extracted from whole kidneys, and there were no significant differences in levels of $\mathrm{AT}_{1 \mathrm{~B}}$ mRNA expression between the lpr-KO mice $(1.31 \pm 0.17$ $\mathrm{AU})$ and the lpr controls (1.00 $\pm 0.14 \mathrm{AU} ; P=\mathrm{NS})$.

\section{Figure 3}

Kidney injury is augmented in Ipr-KO mice. High-power views of representative glomeruli from $\mathrm{H} \& \mathrm{E}$-stained sections of kidneys from $/ \mathrm{pr}$ (A) and Ipr-KO (B) mice at 12 weeks of age. Original magnification, $\times 600$. Typical of MRL-Fas $/$ pr/lpr mice at this age, glomerular pathology in the Ipr group was relatively mild. In contrast, glomeruli from Ipr-KO mice showed severe pathology including hypercellularity, focal necrosis, mesangial expansion, and glomerulosclerosis. Representative low-power views of kidneys from $/ p r$ (C) and Ipr-KO (D) mice. Original magnification, $\times 200$. There was minimal interstitial infiltration in kidneys from Ipr mice (C). In contrast, robust mononuclear cell infiltrates were observed in kidneys from Ipr-KO animals (D), especially in perivascular regions. Typical small renal arteries from Ipr (E) and Ipr-KO (F) mice depict preservation of normal structure in the lpr control $(\mathbf{E})$, with abnormal vascular architecture in the Ipr-KO mice $(\mathbf{F})$ characterized by inflammation and reactive hyperplasia with thickening and sclerosis of the arterial wall. Original magnification, $\times 600$. (G) Prevalence of vascular pathology in Ipr and Ipr-KO kidneys comparing medium and large vessels ${ }^{*} P<0.001$ and ${ }^{\#} P=0.002$ versus $/ p r$ by $\chi^{2}$ test. $n=19$ for Ipr group (9 males and 10 females); $n=24$ for the Ipr-KO group (14 males and 10 females).

To further characterize the pattern of expression of the $\mathrm{AT}_{1 \mathrm{~B}}$ receptor within the kidney, we compared levels of $\mathrm{AT}_{1 \mathrm{~B}}$ receptor mRNA from whole kidney and isolated glomeruli from wild-type mice. $\mathrm{AT}_{1 \mathrm{~B}} \mathrm{mRNA}$ levels in the glomerulus were nearly 4 times higher those in whole kidney extract $(1.39 \pm 0.70$ vs. $0.37 \pm 0.21$ $\mathrm{AU})$, consistent with previous studies suggesting predominant renal expression of the $\mathrm{AT}_{1 \mathrm{~B}}$ receptor in the glomerulus (30-32). To further evaluate $\mathrm{AT}_{1 \mathrm{~B}}$ mRNA expression in various glomerular cell populations, we used FACS to isolate glomerular podocytes or endothelial cells from respective lines of transgenic mice expressing cyan fluorescent protein (CFP) specifically in podocytes (nephrin-CFP) or GFP specifically in endothelial cells (Flk1-GFP). $\mathrm{AT}_{1 \mathrm{~B}}$ mRNA levels in these freshly sorted cells were compared with those in a mouse mesangial cell line. Using this approach, we found expression of $\mathrm{AT}_{1 \mathrm{~B}}$ receptors in sorted cell populations enriched for podocytes $(4.39 \pm 2.68 \mathrm{AU})$, but $\mathrm{AT}_{1 \mathrm{~B}}$ expression was not detectable in the freshly isolated glomerular endothelial cells or cultured mesangial cells.

To examine the role of the glomerular $\mathrm{AT}_{1 \mathrm{~B}}$ receptor in promoting kidney injury, we treated $l p r$-KO animals with losartan, a potent and specific blocker of both the $\mathrm{AT}_{1 \mathrm{~A}}$ and $\mathrm{AT}_{1 \mathrm{~B}}$ receptor isoforms, and evaluated its effects on the course of renal disease. Losartan treatment was initiated at 4 weeks of age, after renal development is complete but before significant renal injury becomes evident in the MRL/lpr model. Treatment of $l p r$-KO mice with losartan for 8 weeks caused a marked reduction in albuminuria from $233 \pm 135$ $\mu \mathrm{g} / 24 \mathrm{~h}$ in $l p r-\mathrm{KO}$ mice receiving water alone to $46 \pm 4 \mu \mathrm{g} / 24 \mathrm{~h}$ in $l p r$-KO mice treated with losartan $(P<0.007)$. Indeed, the level of albuminuria in the $l p r$-KO mice given losartan was no different than that of untreated lpr controls $(39 \pm 4 \mu \mathrm{g} / 24 \mathrm{~h} ; P=\mathrm{NS})$. Consistent with its effects on albuminuria, treatment with the $\mathrm{AT}_{1}$ receptor blocker also reduced the extent of glomerulosclerosis in lpr-KO mice by nearly $40 \%$ from $12 \% \pm 2 \%$ to $21 \% \pm 4 \%(P=0.03)$. However, losartan did not affect interstitial mononuclear cell infiltration or the severity of vascular pathology.

Based on our finding that renal expression of $\mathrm{AT}_{1 \mathrm{~B}}$ receptors is primarily confined to glomerular podocytes, we examined the extent of podocyte injury in kidneys from the experimental groups ( $n=10 \mathrm{lpr}$-KO mice; $n=11 \mathrm{lpr}$ controls) by immunostaining for 
A

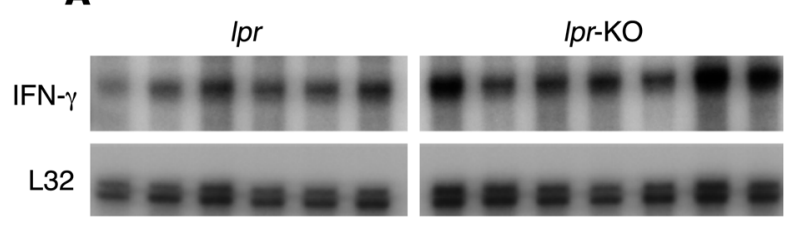

C

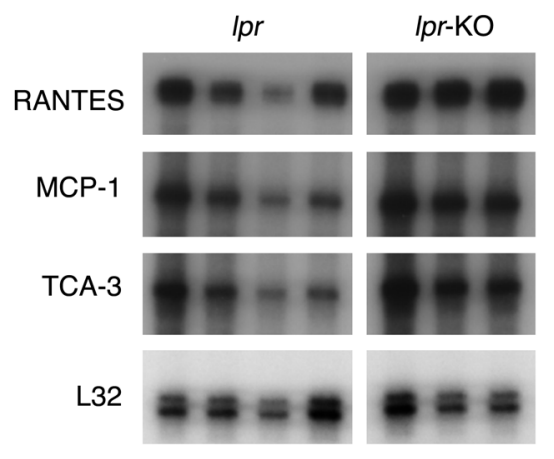

E

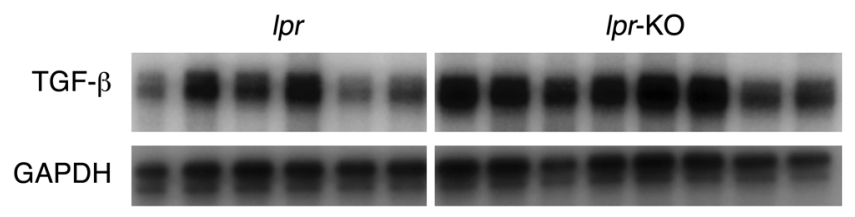

B
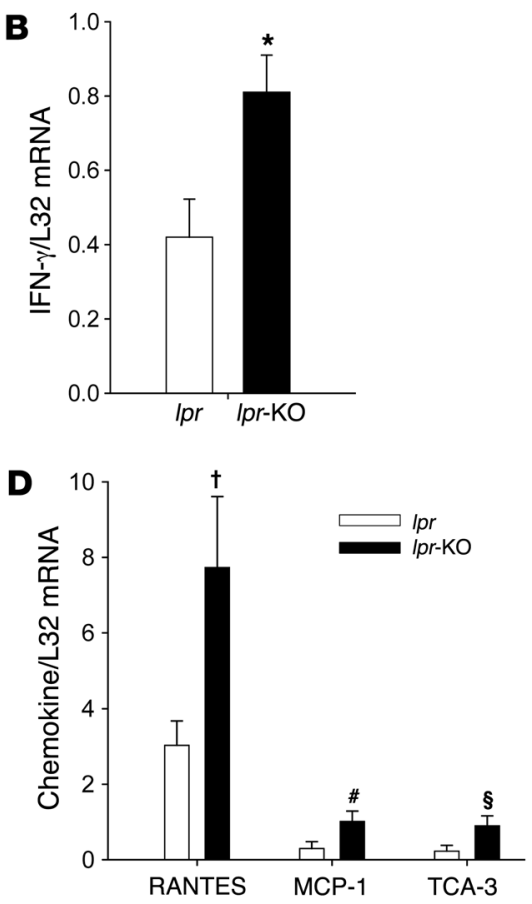

$\mathbf{F}$

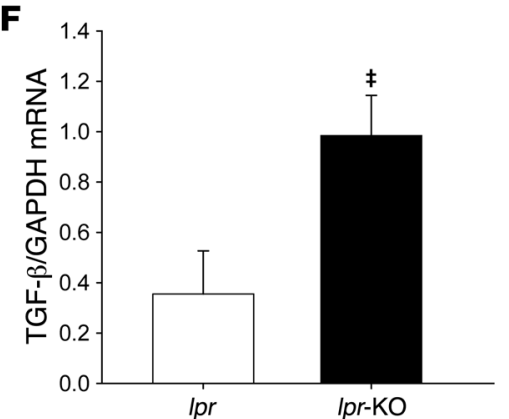

Figure 4

Enhanced mRNA expression for cytokines and chemokines in kidneys from Ipr-KO mice. (A) Levels of mRNA for IFN- $\gamma$ and housekeeping gene L32 assessed by RNAse protection assay (RPA) in male kidneys at 12 weeks of age; the lanes were run on the same gel but were noncontiguous. (B) Plot of the corresponding analysis by densitometry; mRNA levels for IFN- $\gamma$ were significantly increased in Ipr-KO mice. ${ }^{*} P<0.02$ versus Ipr controls. $n \geq 6$ per group. (C) mRNA levels for selected chemokines and the housekeeping gene L32 assessed by RPA; the lanes were run on the same gel but were noncontiguous. (D) Corresponding plot of the densitometry analysis; levels of mRNA for RANTES, MCP-1, and TCA-3 were all significantly increased in kidneys from Ipr-KO mice. ${ }^{\dagger} P=0.03, \S P=0.04$, and $\# P=0.05$ versus $/ p r$ controls. $n \geq 4$ per group. (E) Kidney mRNA expression for TGF- $\beta$ and the housekeeping gene GAPDH; the lanes were run on the same gel but were noncontiguous. (F) Corresponding densitometry analysis; TGF- $\beta$ mRNA expression was significantly increased in kidneys of Ipr-KO mice. $\ddagger P=0.02$ versus $I p r . n \geq 6$ per group.

desmin. Desmin is normally expressed in mesangial cells but not in podocytes. However, expression in podocytes is triggered by injury, and it has therefore been used as a reliable marker of podocyte damage $(33,34)$. As can be seen in Figure 8 , modest and equivalent levels of desmin staining were seen in the glomerular mesangial cells from the kidneys in each experimental group, confirming the technical adequacy of staining. On the other hand, desmin staining in podocytes was detected in only 1 of 11 kidneys from $l p r$ mice (9.1\%). In contrast, robust podocyte staining for desmin was seen in 8 of $10 \mathrm{lpr}$-KO kidneys ( $80 \% ; P<0.002$ by Fisher's exact test). Thus, podocyte damage was a major feature of glomerular disease in 12 -week-old $l p r$-KO mice but was only rarely seen in $l p r$ controls.
Glomerular $A T_{1}$ receptors augment expression of inflammatory mediators in the kidney. To determine whether blockade of the $\mathrm{AT}_{1 \mathrm{~B}}$ receptor affected expression of key inflammatory mediators associated with progression of lupus nephritis, we again performed RNAse protection assay on the kidneys from the lpr-KO mice treated with vehicle or losartan. Expression of IFN- $\gamma$ was dramatically reduced in the kidneys from $0.15 \pm 0.03 \mathrm{AU}$ in the vehicle group to $0.04 \pm 0.02 \mathrm{AU}$ in the losartan-treated animals $(P<0.02)$ despite the persistence of renal mononuclear cell infiltrates in this group. In addition, losartan significantly attenuated expression of TGF- $\beta$ in $l p r$-KO animals $(1.15 \pm 0.05$ vs. $1.79 \pm 0.22 \mathrm{AU} ; P<0.01)$, suggesting that a major pathway for stimulation of TGF- $\beta$ expression in this setting is mediated by activation of the glomerular $\mathrm{AT}_{1 \mathrm{~B}}$ receptor. 

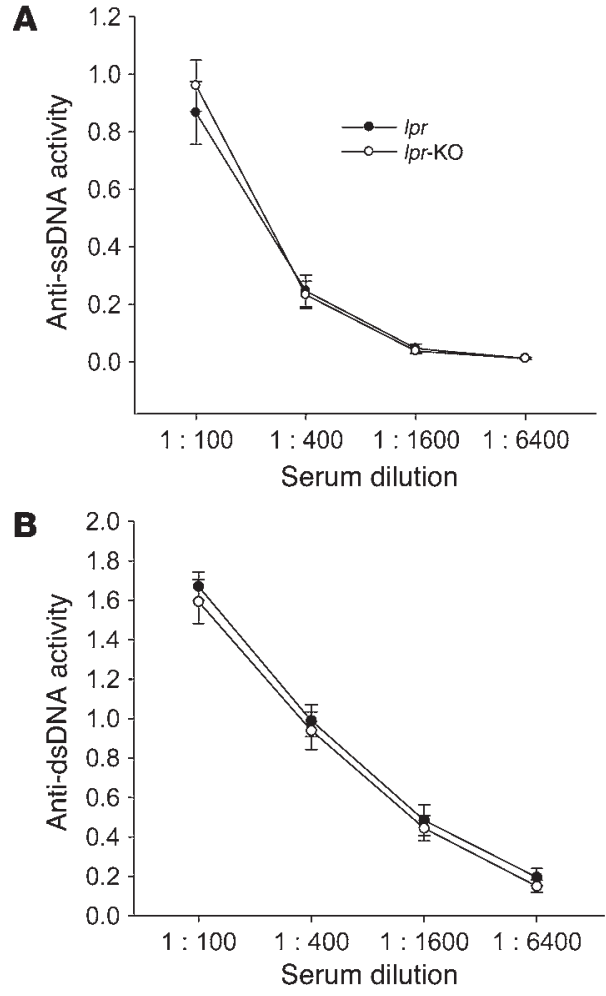

\section{Discussion}

Abnormal activation of the RAS contributes to the pathogenesis of a range of disorders including hypertension, congestive heart failure, and diabetic kidney disease (35-37). Pharmacological and genetic studies have demonstrated that activation of $\mathrm{AT}_{1}$ receptors by angiotensin II is a key pathway driving pathology in these disorders (35-38). Along with the $\mathrm{AT}_{1}$ receptor's effects on blood pressure levels and fluid homeostasis, recent studies have suggested that $\mathrm{AT}_{1}$ receptors may also modulate immune and inflammatory responses $(5,39,40)$. Moreover, these proinflammatory

\section{Figure 5}

IgG anti-DNA antibody activity in serum from MRL-Fas Ipr/lpr experimental groups. (A) Anti-ssDNA and (B) anti-dsDNA antibody activity was determined by ELISA on serum from MRL-Fas/pr/lpr mice lacking $\mathrm{AT}_{1 \mathrm{~A}}$ receptors $(I \mathrm{pr}-\mathrm{KO})$ and $/ p r$ controls at 12 weeks of age. $n=20$ for the Ipr group (10 males and 10 females); $n=24$ for the Ipr-KO mice (14 males and 10 females).

actions may contribute to end-organ damage in disorders such as hypertension and coronary disease $(4,40,41)$, as well as immunological processes such as transplant rejection $(5,42)$. Thus, we were interested in exploring the role of this ligand-receptor pathway in autoimmune disease, focusing on effects in immune-mediated glomerulonephritis.

Previous studies have shown that administration of ACE inhibitors or angiotensin receptor blockers attenuates autoimmune disease in murine lupus models, reducing the severity of glomerular damage $(10,11,43)$. Accordingly, we anticipated that elimination of $\mathrm{AT}_{1 \mathrm{~A}}$ receptors from the MRL-fas $\mathrm{pr}^{\mathrm{r} / \mathrm{lpr}}$ background would be protective. Yet we found that autoimmune nephritis was significantly accelerated by $\mathrm{AT}_{1 \mathrm{~A}}$ receptor deficiency. This was manifested by early mortality with increased proteinuria and severe kidney pathology. Despite the marked worsening of renal disease and consequent early mortality, the extent of lymphadenopathy was not affected and the number of abnormal "double-negative" lymphocytes characteristic of this model was similar in $\mathrm{AT}_{1 \mathrm{~A}}$-deficient animals and $l p r$ controls. Similarly, elimination of $\mathrm{AT}_{1 \mathrm{~A}}$ receptors did not affect autoantibody levels or the extent of autoimmune injury in extrarenal tissues including skin, heart, and joints.

To determine whether this unexpected result was due to altered function of autoimmune lymphocytes, we transplanted bone marrow from $l p r$ or $l p r-\mathrm{KO}$ donors into syngeneic $l p r$ recipients. The mean survival of $l p r-\mathrm{KO} \rightarrow l p r$ bone marrow chimeras lacking $\mathrm{AT}_{1 \mathrm{~A}}$ receptors only in hematopoietic cell lineages was virtually identical to that of $l p r \rightarrow l p r$ transplanted controls with normal expression of $\mathrm{AT}_{1 \mathrm{~A}}$ receptors. We therefore concluded that the absence of $\mathrm{AT}_{1 \mathrm{~A}}$

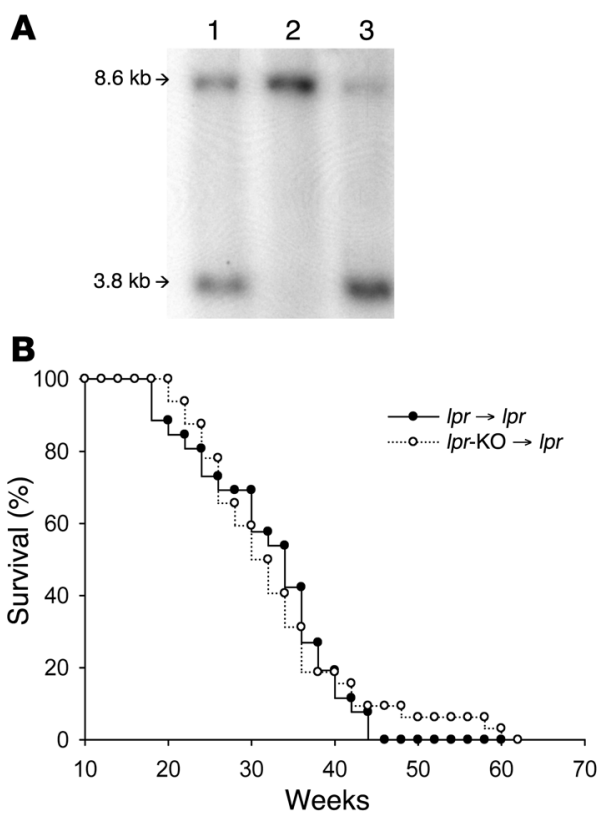

\section{Figure 6}

Absence of $\mathrm{AT}_{1 \mathrm{~A}}$ receptors on bone marrow-derived cells does not account for the accelerated mortality of $I p r-K O$ mice. (A) Southern blot analysis of genomic DNA isolated from splenocytes, digested with $B a m H 1$, and hybridized with a DNA probe that distinguishes the 8.6-kb fragment generated from the wild-type Agtr1a allele and the $3.8-\mathrm{kb}$ fragment identifying the targeted allele (1). Samples: lane 1, nontransplanted MRL-Fas $/$ pr/liprAgtr1a ${ }^{+/}$control; both bands are present with equal intensi-

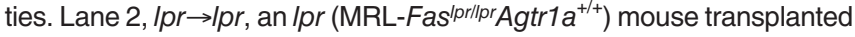
with $I p r$ bone marrow; only the wild-type band is observed. Lane 3, Ipr$\mathrm{KO} \rightarrow \mid \mathrm{pr}$, an $/ \mathrm{pr}$ mouse transplanted with bone marrow from an $/ \mathrm{pr}$-KO

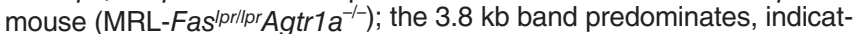
ing that the majority of cells in the sample ( $98.3 \%$ by densitometry) come from the donor. (B) Survival of MRL/lpr mice transplanted with wild-type versus Agtr1 $^{-/-}$bone marrow. Survival of Ipr mice $(n=26 ; 12$ males, 14 females) transplanted with bone marrow from Ipr donors was virtually identical to the mean survival of $I p r$ animals $(n=32 ; 17$ males, 15 females) transplanted with $/ p r-\mathrm{KO}$ bone marrow lacking $\mathrm{AT}_{1 \mathrm{~A}}$ receptors (230 \pm 11 versus $234 \pm 8$ days; $P=$ NS). 


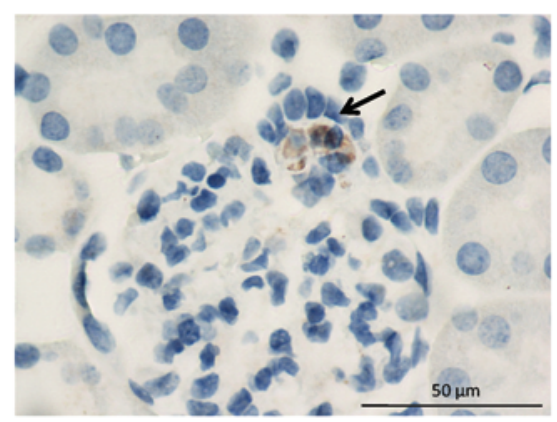

Figure 7

Renin protein immunostaining in the JGA of a kidney from an Ipr-KO mouse. Kidney sections from Ipr and Ipr-KO mice were stained for renin using a specific antibody as described. The number of glomeruli with detectable staining for renin protein in the JGA was significantly higher in the Ipr-KO mice ( $n \geq 12$ mice per group; 127 out of 419 glomeruli: $30.3 \%$ ) versus controls (59 out of 328 glomeruli: $18.0 \%$; $P<0.0001)$. Photomicrograph shows a representative glomerulus with positive staining for renin. Arrow points to renin-containing juxtaglomerular cells. Original magnification, $\times 100$.

receptors on lymphocytes or other cell lineages derived from bone marrow does not explain the enhanced severity of disease in the $l p r$-KO mice. Since previous studies by our group and others have suggested that activation of $\mathrm{AT}_{1}$ receptors can stimulate cellular immune responses $(5,41)$, it is likewise notable that the isolated absence of $\mathrm{AT}_{1 \mathrm{~A}}$ receptors from immune cell populations did not prolong survival of $l p r$ mice in this setting. Taken together, these findings suggest that effects of $\mathrm{AT}_{1}$ receptors on lymphocytes do not contribute significantly to either augmenting or attenuating the severity of this autoimmune disease.

Since an enhanced cellular immune response is not the mechanism driving accelerated disease in $l p r-\mathrm{KO}$ mice, we next considered the possibility that other systemic consequences of $\mathrm{AT}_{1 \mathrm{~A}}$ receptor deficiency might play a role. Previous studies have shown that genetic deletion of $\mathrm{AT}_{1 \mathrm{~A}}$ receptors is associated with marked stimulation of renin expression (24) due to the absence of $\mathrm{AT}_{1 \mathrm{~A}}$ receptor signaling in the juxtaglomerular cells, with resulting attenuation of short-loop feedback inhibition of renin release $(24,25)$. Increased renin expression in $\mathrm{AT}_{1 \mathrm{~A}}$ receptor-deficient mice leads to increases in circulating levels of angiotensin II (26). Indeed, we found that renin mRNA expression was increased more than 3-fold and JGA renin protein was significantly augmented in the $l p r$-KO animals, indicating significant activation of the RAS and suggesting that stimulation of residual elements of the system might be a mechanism promoting exaggerated kidney disease.

Of the 2 classes of angiotensin receptors, $\mathrm{AT}_{1}$ receptors mediate most of the classical functions of the RAS in physiology and disease, whereas $\mathrm{AT}_{2}$ receptors generally oppose or attenuate the actions of $\mathrm{AT}_{1}$ receptors $(38,44)$. The lpr-KO mice lack the major murine $\mathrm{AT}_{1}$ receptor, $\mathrm{AT}_{1 \mathrm{~A}}$, but expression of the minor isoform, $\mathrm{AT}_{1 \mathrm{~B}}$, is preserved in these animals. In the kidney, it has been reported that $\mathrm{AT}_{1 \mathrm{~B}}$ receptor expression is largely limited to the glomerulus (31). We have confirmed the predominance of $\mathrm{AT}_{1 \mathrm{~B}}$ expression in the glomerulus and have shown that this expression is primarily concentrated in podocytes. Thus, the $\mathrm{AT}_{1 \mathrm{~A}}$-deficient mouse line provides a fortuitous model wherein renal $\mathrm{AT}_{1}$ receptor expression is limited to the glomerulus. Accordingly, we postu- lated that the systemic activation of the RAS seen in lpr-KO mice promotes aggressive kidney disease by stimulating the residual glomerular $\mathrm{AT}_{1 \mathrm{~B}}$ receptors.

To test this directly, we administered a potent and specific $\mathrm{AT}_{1}$ receptor antagonist (losartan) to $l p r$-KO mice and assessed effects on the severity of kidney disease. In lpr-KO mice, blockade of glomerular $\mathrm{AT}_{1 \mathrm{~B}}$ receptors with losartan dramatically reduced proteinuria and markedly attenuated renal structural damage. Interestingly, treatment with losartan did not reduce the interstitial mononuclear cell infiltrates, consistent with previous reports that these lymphoid aggregates in the kidney may be an indicator of the lpr lymphoproliferative phenotype rather than a marker for the severity of kidney damage (11). Taken together, these data suggest that activation of glomerular $\mathrm{AT}_{1 \mathrm{~B}}$ receptors is a powerful pathway promoting functional injury in autoimmune nephritis, and this mechanism likely explains the accelerated glomerular disease seen in the untreated lpr-KO mice. More broadly, these data identify potent interactions between autoimmunity and RAS activation to augment glomerular pathology.

An important role for $\mathrm{AT}_{1}$ receptors in the pathogenesis of kidney diseases has been well documented, but the specific pathways linking the $\mathrm{AT}_{1}$ receptor to the development of proteinuria and structural injury have been difficult to precisely define in vivo. In other settings, $\mathrm{AT}_{1}$ receptor-mediated systemic hypertension is thought to be a major contributor to proteinuria and the progression of kidney disease (37). However, an effect on blood pressure levels is clearly not a factor in lpr-KO mice since they do not have hypertension; in fact, their blood pressure levels are significantly lower than those of the $l p r$ controls. It has also been suggested that stimulation of $\mathrm{AT}_{1}$ receptors in the glomerular microcirculation contributes to proteinuria and structural damage by increasing glomerular hydrostatic pressures $(45,46)$ due to the predominant constriction of efferent arterioles caused by angiotensin II (45-47). $\mathrm{AT}_{1 \mathrm{~B}}$ receptors are expressed in afferent but not efferent arterioles $(30,32)$. In the blood-perfused juxtamedullary nephron preparation, activation of $\mathrm{AT}_{1 \mathrm{~B}}$ receptors in isolation causes a predomi-
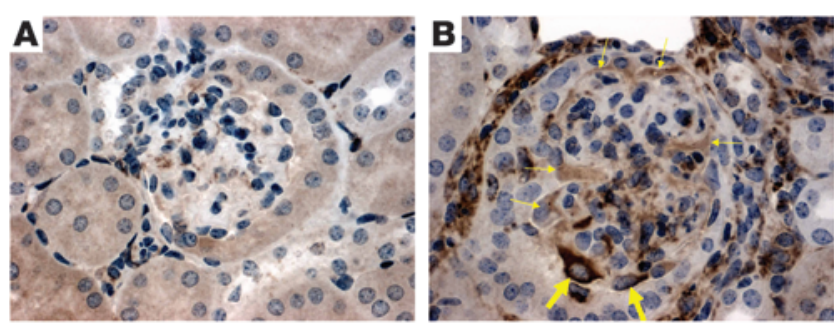

\section{Figure 8}

Enhanced podocyte injury in kidneys from /pr-KO mice. Immunostaining for desmin, a marker of podocyte injury, was carried out in sections of kidneys from $\operatorname{lpr}(n=11 ; 7$ males and 4 females) and $/ p r$-KO mice $(n=10$; 6 males and 4 females). (A) A representative glomerulus from an Ipr mouse shows no staining for desmin in podocytes, with very focal staining for desmin in the mesangial cell cytoplasm (1+ to $2+)$. (B) In the representative glomerulus from an Ipr-KO mouse, the podocytes are hyperplastic, with positive staining for desmin in the cytoplasm varying in intensity from $1+$ to $2+$ (thin arrows) to $3+$ (thick arrows). The mesangial cell cytoplasm is also strongly positive for desmin (3+). Very focal staining is also noted in some parietal epithelial cells and in interstitium, probably reflecting increased numbers of fibroblasts. Positive staining from desmin in podocytes was found in $80 \%$ of $I p r-K O$ kidneys versus $9 \%$ of $/ p r$ control kidneys $(P<0.002)$. Original magnification, $\times 40$. 
nant constriction of the afferent arteriole $(30,32)$ which would be expected to reduce glomerular hydrostatic pressure. These data suggest that a maladaptive alteration in glomerular hemodynamics mediated by activation of $\mathrm{AT}_{1 \mathrm{~B}}$ receptors in isolation would be an unlikely cause of augmented proteinuria and kidney pathology in $l p r$-KO mice, especially in view of the low systemic blood pressure levels in these animals. However, we did not measure glomerular pressures in our experiments and it is possible that the character of this response described in the ex vivo system might be different in the intact animal.

In the absence of an apparent hemodynamic cause for accelerated nephritis in $l p r-\mathrm{KO}$ mice, it follows that these effects must be a direct consequence of activation of $\mathrm{AT}_{1 \mathrm{~B}}$ receptors in specific glomerular cell populations. Our studies show that within the glomerulus, $\mathrm{AT}_{1 \mathrm{~B}}$ receptors are primarily expressed in podocytes, a key constituent of the glomerular filter. Moreover, recent studies have established a central role for podocyte dysfunction in the pathogenesis of a variety of kidney diseases (48-50). Experiments in cultured podocytes suggest that $\mathrm{AT}_{1}$ receptors regulate critical functions including proliferation and apoptosis (51-54). Thus, we suggest that accelerated glomerular disease in $l p r-\mathrm{KO}$ mice is a direct consequence of $\mathrm{AT}_{1 \mathrm{~B}}$ receptor activation in podocytes and is clearly independent of effects of angiotensin II on systemic blood pressure. Moreover, using immunostaining for desmin, we found clear evidence for exaggerated podocyte injury in $l p r$-KO mice.

Enhanced expression of cytokines in the kidney has been suggested to play a key role in the pathogenesis of autoimmune nephritis $(55,56)$. For example, tissue expression of IFN- $\gamma$ is significantly upregulated in $l p r$ mice (57) and studies using knockout mice support a causal role for IFN- $\gamma$ in disease pathogenesis $(56,58-60)$. Similarly, TGF- $\beta$ expression in the kidney is thought to be a final common pathway leading to the development of structural damage and fibrosis in a range of glomerular diseases (61-63). In our studies, expression of both IFN- $\gamma$ and TGF- $\beta$ were markedly increased in kidneys of $l p r$-KO mice compared with those of $l p r$ controls. This enhanced expression was significantly ameliorated by treatment with losartan. These findings suggest that activation of glomerular $\mathrm{AT}_{1}$ receptors, presumably in podocytes, is sufficient to markedly augment expression of key inflammatory cytokines implicated in the pathogenesis of autoimmune glomerulonephritis. These proinflammatory actions are independent of effects on peripheral lymphocytes, which do not express $\mathrm{AT}_{1 \mathrm{~B}}$ receptors, and therefore appear to be a direct consequence of glomerular $\mathrm{AT}_{1}$ receptor activation.

In summary, genetic deletion of $\mathrm{AT}_{1 \mathrm{~A}}$ receptors from the MRLFas ${ }^{l p r / p r}$ background accelerates mortality, increases proteinuria, and augments the severity of kidney pathology. Activation of residual populations of glomerular $\mathrm{AT}_{1 \mathrm{~B}}$ receptors in podocytes is the mechanism responsible for the more severe renal disease in $\mathrm{AT}_{1 \mathrm{~A}}$ receptor-deficient lpr animals. These studies clearly define for the first time the potent capacity for cellular actions of glomerular $\mathrm{AT}_{1}$ receptors in isolation to promote proteinuria, to stimulate proinflammatory cytokine expression, and to induce structural injury in vivo in a manner that is independent of systemic hypertension or other hemodynamic perturbations. Conversely, even in the absence of hypertension, blockade of these glomerular receptors provides powerful protection against kidney damage. Based on the action of renal $\mathrm{AT}_{1}$ receptors to induce kidney damage in autoimmune nephritis, blockade of the RAS with ACE inhibitors or ARBs may be useful in protecting the kidney in patients with lupus or other autoimmune disorders.

\section{Methods}

Mice. All mice were bred and maintained in pathogen-free animal barrier facilities at the Durham VA Medical Center under local and NIH guidelines. All animal studies were approved by the Institutional Animal Care and Use Committee, Durham Veterans Affairs Medical Center (Durham, North Carolina, USA). MRL/MpJ and MRL/MpJ-Tnfrsf6lpr (MRL/lpr) mice were purchased from The Jackson Laboratory. Mice with a targeted deletion of the $\mathrm{AT}_{1 \mathrm{~A}}$ receptor gene locus (Agtr1a) were generated as previously described (1). Agtrla $a^{+/-}$MRL/MpJ mice were generated through repeated backcrosses for more than 10 generations. Successive intercrosses with $\mathrm{MRL} / \mathrm{lpr}$ animals yielded groups of $A g t r 1 a^{+/+}(l p r)$ and $l p r$-KO littermates used for our experiments. $24 \mathrm{lpr}$ (10 males and 14 females) and $18 \mathrm{lpr}$-KO mice ( 8 males and 10 females) were maintained indefinitely for long-term survival assessment. For disease progression studies at 12 weeks of age, there were $19 \mathrm{lpr}$ mice ( 9 males and 10 females) and $24 \mathrm{lpr}$-KO mice (14 males and 10 females).

Evaluation of lymphoid organs. 24 hours following the urine collection, the 12 -week-old animals were anesthetized, blood was collected via intracardiac puncture, and the left kidney, spleen, thymus, and left axillary lymph node were removed for analysis as described below. Blood samples were centrifuged for 6 minutes at $3,800 \mathrm{~g}$. The sera were stored at $-80^{\circ} \mathrm{C}$. Spleen, thymus, and lymph node tissues were weighed and placed in ice-cold RPMI media with $10 \%$ heat-inactivated FCS for flow cytometry. Portions of kidney and heart tissue were snap-frozen and stored at $-80^{\circ} \mathrm{C}$ for extraction of RNA. The remainder of the kidney was fixed in $10 \%$ buffered formalin.

Assay of lymphocyte populations. Single-cell suspensions were prepared from spleens, thymuses, and lymph nodes of $l p r$ and $l p r$-KO animals $(n=8$ per group $)$ isolated as above. Cells $\left(1 \times 10^{6} / \mathrm{ml}\right)$ were washed, rested for 15 minutes in RPMI containing $10 \%$ FCS to reduce nonspecific binding, and resuspended in PBS containing $2 \%$ FCS and $0.02 \%$ sodium azide. The cells were then stained in $200 \mu \mathrm{l}$ volumes at $4^{\circ} \mathrm{C}$ using predetermined optimal concentrations of antibodies. All antibodies and isotype controls were purchased from BD Biosciences. The antibodies used were as follows: PE-labeled anti-CD3; FITC-labeled anti-CD4; Cy5-labeled anti-CD8; FITClabeled anti-B220/CD45R; PE-labeled NK1.1; PE-labeled F4/80; PE-labeled anti-CD25; and PE-, FITC-, and Cy5-labeled isotype antibodies. After final washing, cells were fixed in PBS containing $2 \%$ formalin and analyzed within 72 hours. Analyses were performed on a FACSCalibur (BD Biosciences) at the Flow Cytometry Facility at Duke University.

Measurement of autoantibody levels. Anti-DNA antibody levels were determined by ELISA as previously described using, as antigen, photobiotinylated ssDNA and dsDNA added to streptavidin-coated plates $(64,65)$. For this purpose, the ssDNA and dsDNA were first biotinylated according to the manufacturer's instructions (Vector Laboratories). Immulon 2HB microtiter plates (ThermoLab) were coated with Streptavidin (Sigma-Aldrich) at $5 \mu \mathrm{g} / \mathrm{ml}$ in $0.1 \mathrm{M}$ phosphate buffer, $\mathrm{pH} 9.0,100 \mu \mathrm{l} /$ well, and incubated overnight at $4{ }^{\circ} \mathrm{C}$. After 3 washes with PBS, biotinylated DNA at $0.2 \mu \mathrm{g} / \mathrm{ml}$ was added to wells and incubated at room temperature for 1 hour. Serum diluted 1:100 in PBS-Tween (PBS containing 0.5\% of Tween-20) was added in duplicate and incubated for 1 hour. Then, $100 \mu \mathrm{l}$ of peroxidase-conjugated goat anti-mouse IgG (heavy and light chains; Sigma-Aldrich) diluted 1:1000 in PBS-Tween was added, and after 1 hour incubation, followed by $200 \mu \mathrm{l}$ of the substrate containing $0.015 \%$ of $3,3^{\prime}, 5,5^{\prime}$-tetramethylbenzidine (TMB) (Sigma-Aldrich) in $0.1 \mathrm{M}$ citrate buffer, $\mathrm{pH} 4.0$, and $0.01 \%$ hydrogen peroxide for color development. After 35 minutes incubation, OD380 was determined with a microtiter plate reader (Molecular Dynamics).

Bone marrow cell transplantation. Bone marrow cells were obtained by flushing the femurs and tibiae of 1-month-old donor $l p r$ or $l p r$-KO mice with RPMI 1640 medium supplemented with 10\% FCS as described (66). After counting, cells were then resuspended in PBS at $4 \times 10^{7}$ cells $/ \mathrm{ml}$. Recipient 
lpr mice were lethally irradiated with 10.5 Gy using a cesium irradiator (67). Within 4 hours after irradiation, the mice were injected intravenously via tail vein with $10^{7}$ cells (66-68). To avoid immunologic responses due to the $\mathrm{H}-\mathrm{Y}$ antigen, male recipients received male bone marrow cells and females received female bone marrow cells. Mortality was recorded daily. At least 26 viable transplants were performed in each group.

Detection of donor chimerism. To confirm repopulation of the recipient lymphoid organs with donor bone marrow-derived cells, Southern blot analysis was performed on DNA from recipient splenocytes as previously described (68). In brief, splenocytes were harvested from recipients 8 weeks following bone marrow transplantation. The splenocytes were resuspended in sterile rbc lysis buffer $\left(150 \mathrm{mM} \mathrm{NH}_{4} \mathrm{Cl}, 10 \mathrm{mM} \mathrm{KHCO}_{3}, 130 \mathrm{mM}\right.$ EDTA $)$ and incubated for 4 minutes at room temperature to remove red blood cells as described (69), then washed in PBS to yield purified mononuclear cells. DNA was then extracted from the mononuclear cells, digested with $B a m H I$, and analyzed by Southern blot analysis as described (1). Insertion of the Agtr1 $a^{-/-}$targeting vector into the locus introduced another BAMHI site, so that the targeted allele could be identified by the presence of a diagnostic 3.8-kb BamHI fragment using an Agtr1a probe as reported elsewhere (1). The extent of bone marrow chimerism was determined by densitometric analysis of the autoradiogram.

Biochemical measurements for kidney injury. At 12 weeks of age, urine was collected from mice individually housed in specially designed metabolic cages with free access to tap water. Urine was collected for 24 hours and stored at $-80^{\circ} \mathrm{C}$. Urinary albumin concentration was determined using an indirect competitive ELISA according to the manufacturer's instructions (Albuwell M; Exocell). BUN levels were quantitated using a Vitros 250 Chemical Analyzer (Ortho Clinical Diagnostic).

Histopathological evaluations. Fixed kidney tissues were embedded in paraffin, sectioned, and stained with H\&E. All of the tissues were examined by a pathologist (P. Ruiz) without knowledge of the experimental groups. The kidney sections were graded based on the presence and severity of abnormalities in glomeruli, tubules, vessels, and interstitium. As previously described $(16,70)$, the severity of renal pathological abnormalities was graded using a semiquantitative scale, in which 0 represented no abnormalities, and 1+, 2+, 3+, and 4+ represented mild, moderate, moderately severe, and severe abnormalities, respectively. An overall histologic score for each kidney was obtained by summing the individual grades for the glomeruli, tubules, and interstitium, plus 1 point for the presence of vascular damage or arterial stenosis (64). Percentage glomerulosclerosis is defined as the number of glomeruli with evidence of sclerosis divided by the total number of glomeruli in the section. For the analysis of knee joints, knees were dissected from the right hind limb and fixed in $10 \%$ buffered formalin. The joints were decalcified, paraffin-embedded, and stained with H\&E. Joints were then evaluated for proliferation of the synovial lining and stroma cells, fibrosis of the synovial membrane, and presence of lymphocytes, macrophages, and granulomas. Grading was performed using a 4-point semiquantitative scale as described $(21,64)$.

RNase protection assays. Total cellular RNA was extracted from kidney tissues using the RNeasy kit (QIAGEN), according to the manufacturer's instructions and was stored in RNase-free water at $-80^{\circ} \mathrm{C}$. To detect cytokine mRNA, commercially available multiprobe template sets (RiboQuant; BD Biosciences) were labeled with $[\alpha-32 \mathrm{P}] \mathrm{UTP}$ (PerkinElmer) according to manufacturer's instructions and then diluted to a concentration of 300,000 $\mathrm{cpm} / \mu \mathrm{l}$ of hybridization buffer. All reagents used in probe synthesis were obtained from BD Biosciences (45004K; In Vitro Transcription Kit). The following probe sets were used: $M C K-1$ (IL-4, IL-5, IL-10, IL-13, IL-15, IL-9, IL-2, IL-6, IFN- $\gamma$ ), $m C K-3 b$ (LT, TNF, IL-6, IFN- $\gamma$, IFN- $\beta$, TGF- $\beta 1$, TGF- $\beta 2$, TGF- $\beta 3$, MIF), and $m C K-5 c$ (Ltn, RANTES, MIP-1b, MIP-1a, MIP-2, IP-10, MCP-1, TCA-3, eotaxin). RNase protection assays were performed using the RNase
Protection Assay Kit (45014K; BD Biosciences) and following the protocol suggested by the manufacturer. Samples were then heat blocked $\left(95^{\circ} \mathrm{C}\right)$ for 3 minutes and run on acrylamide gels. Gels were covered with Saran Wrap (SC Johnson) and dried under vacuum at $80^{\circ} \mathrm{C}$ for 45 minutes. The dried gels were placed on film in a cassette with an intensifying screen and stored at $-80^{\circ} \mathrm{C}$. The exposure time ranged from 2 hours (for the housekeeping genes) to 7 days (for faint bands). Films were developed and scanned and bands were analyzed as a ratio of target RNA/housekeeping gene control using the Scion Image for Windows program, version 4.02.

Tail-cuff blood pressure measurements. Systolic blood pressure levels were determined in conscious mice by the noninvasive computerized tail-cuff method after 2 weeks of daily training, which involved placing the mouse into the blood pressure-measuring apparatus for acclimation. This method was validated previously and correlates well with direct measurements of intraarterial pressure (1). Data were recorded for 2 weeks. Measurements with SD of more than $30 \mathrm{mmHg}$ for systolic blood pressure levels were not accepted.

Real-time RT-PCR for renin and $A T_{1 B}$ receptor. Relative levels of mRNA for renin were determined by real-time RT-PCR with the ABI Prism 7700 Sequence Detection System (PE Biosystems) as described previously (71). Kidneys were harvested, and total RNA was isolated using an RNeasy Mini Kit per the manufacturer's instructions (QIAGEN). The nucleotide sequences of the PCR primers and their fluorogenic probes have been published previously (71). Real-time RT-PCR amplifications were performed in a 96-well plate in the ABI Prism 7700 sequence detector (PE Biosystems) as previously described (71). A standard plasmid containing a DNA fragment for the renin gene was used as an external control, and amplification of the $\beta$-actin gene was used as an endogenous control. For each experimental sample, the amounts of the target and of the endogenous control were determined according to the appropriate standard curves. Relative levels of mRNA for Agtr1b were similarly determined using the TaqMan Primer Probe Set for Agtr1b (Applied Biosystems) with 18S ribosome as endogenous control.

Measurements of serum aldosterone. At 16 weeks of age, blood was drawn from experimental animals by terminal cardiac puncture and stored at $-70^{\circ} \mathrm{C}$. Aldosterone concentrations were then determined using the CoatA-Count Radioimmunoassay Procedure (Diagnostic Products).

FACS separation of glomerular cell populations for RT-PCR. Kidneys were harvested from transgenic mice with nephrin-CFP (expressed in podocytes) or Flk1-GFP (GFP expressed in endothelial cells) transgenes (72, 73). Glomeruli were isolated by sequential passing through 105 - and 71-micron sieves. Single-cell suspensions were obtained by enzymatic digestion ( $0.2 \%$ tryp$\sin , 0.2 \%$ collagenase $\mathrm{A}, 0.1 \% \mathrm{EDTA}$ in PBS) at $37^{\circ} \mathrm{C}$ for 1 hour on a shaker. After incubation, cells were washed by repeating centrifugation and PBS exchanges. Before sorting, 7-aminoactinomycin was added to exclude dead cells. Cells were then sorted into positive and negative fractions for respective genetic markers by FACS (BD FACSAria; BD Biosciences). Sorting was carried out using low pressure (20 psi) with excitation wavelengths of $407 \mathrm{~nm}$ (CFP) and $488 \mathrm{~nm}$ (GFP) and emission detection filters of 450/40 and 530/30, respectively. The positive fractions were centrifuged, and cells were resuspended in TrizoL for preparation of mRNA. Mesangial cells were obtained from a mouse mesangial cell line (74). In separate experiments, mRNA from kidney cortex and isolated glomeruli was used. mRNA was reverse transcribed to CDNA, and expression of Agtr1b and Hprt (housekeeping gene) was determined by real time PCR as described above. Changes in expression between groups were calculated using the $\Delta \Delta \mathrm{Ct}$ method (Applied Biosystems) and correlated to glomerular expression. Each realtime PCR reaction had a starting cDNA quantity of at least 2 ng. Expression was measured in 3 or more independent preparations per group.

Immunohistochemistry: renin. Renal tissue from 12-week old mice was fixed in formalin and embedded in paraffin. Paraffin-embedded mouse kidney 
sections $(3 \mu \mathrm{m})$ were immunostained by the immunoperoxidase technique using an automatic robot system (Dako), which allowed all slides to be exposed to reagents and antibody for an identical incubation time. Mounted tissue sections were sequentially incubated with normal blocking rabbit serum, primary antibody (rabbit anti-renin polyclonal antibody provided by Tadashi Inagami, Vanderbilt University, Nashville, Tennessee, USA) at 1:4,000 concentration, detected with a rabbit HRP-Polymer kit (Biocare Medical) using DAB (0.1\% 3,3'-diaminobenzidine tetrahydrochloride) (Sigma-Aldrich) to visualize peroxidase activity. In each kidney section, the glomeruli were scored as positive or negative for renin staining localized to juxtaglomerular cells (27). 328 glomeruli from 12 male lpr mice and 419 glomeruli from 12 male $l p r$-KO mice were scored without knowledge of the experimental groups (M.C. Prieto-Carrasquero).

Immunohistochemistry: desmin. Three-micron-thick sections were stained using an avidin-biotin immunoperoxidase technique with polyclonal antibodies against desmin (1:100) (Dako) after antigen retrieval in high $\mathrm{pH}$ water bath for 20 minutes. DAB was used as a detection system, and sections were counterstained with hematoxylin. Sections were then scored for presence or absence of desmin staining in podocytes by a pathologist masked to experimental conditions. $(n=11$ lpr mice, 7 males and 4 females; $n=10 \mathrm{lpr}$-KO mice, 6 males and 4 females).

Antibypertensive therapy. To control for the effects of blood pressure, a separate group of $\mathrm{AT}_{1 \mathrm{~A}}$-receptor wild-type $l \mathrm{pr}$ mice were treated after 4 weeks of age with hydralazine (Sigma-Aldrich), approximately $37 \mathrm{mg} / \mathrm{kg} /$ day in the drinking water $(n=12 ; 6$ males and 6 females). In a subsequent study, we treated Agtr1a-/-MRL/lpr mice with water or $30 \mathrm{mg} / \mathrm{kg}$ body weight/d of losartan provided as a gift by Merck. Animals were treated from 4 weeks of age until 12 weeks of age $(n=23$ for the vehicle-treated group, 11 males and 12 females; $n=25$ for the losartan-treated group, 11 males and 14 females).

Statistics. The values for each parameter within a group are expressed as the mean \pm SEM. For comparisons between groups, statistical significance was assessed using an unpaired 2-tailed Student's $t$ test for normally distributed data. For nonparametric analyses, a Mann-Whitney $U$ test was used. For comparison of proportions of histologic specimens in the experimental groups demonstrating vascular injury, podocyte injury, and juxtaglomerular renin staining, a $\chi^{2}$ or Fisher's exact test was used as stated in the text.

\section{Acknowledgments}

This work was supported in part by grants from the NIH (DK38108 and HL56122) and the Medical Research Service at the Durham VA Medical Center.

Received for publication December 21, 2007, and accepted in revised form February 4, 2009.

Address correspondence to: Thomas M. Coffman, Building 6/ Nephrology (111I), VA Medical Center, 508 Fulton Street, Durham, North Carolina 27705, USA. Phone: (919) 286-6947; Fax: (919) 286-6879; E-mail: tcoffman@acpub.duke.edu.
1. Ito, M., et al. 1995. Regulation of blood pressure by the type 1A angiotensin II receptor gene. Proc. Natl. Acad. Sci. U. S. A. 92:3521-3525.

2. Hilgers, K.F., and Mann, J.F. 2002. ACE inhibitors versus AT(1) receptor antagonists in patients with chronic renal disease. J. Am. Soc. Nephrol. 13:1100-1108.

3. Gray, M.O., Long, C.S., Kalinyak, J.E., Li, H.T., and Karliner, J.S. 1998. Angiotensin II stimulates cardiac myocyte hypertrophy via paracrine release of TGF-beta 1 and endothelin-1 from fibroblasts. Cardiovasc. Res. 40:352-363.

4. Furukawa, Y., Matsumori, A., Hirozane, T., and Sasayama, S. 1996. Angiotensin II receptor antagonist TCV-116 reduces graft coronary artery disease and preserves graft status in a murine model. A comparative study with captopril. Circulation. 93:333-339.

5. Nataraj, C., et al. 1999. Angiotensin II regulates cellular immune responses through a calcineurindependent pathway. J. Clin. Invest. 104:1693-1701.

6. Nishida, M., et al. 2002. Absence of angiotensin II type 1 receptor in bone marrow-derived cells is detrimental in the evolution of renal fibrosis. J. Clin. Invest. 110:1859-1868.

7. Wolf, G., et al. 1997. Angiotensin II stimulates expression of the chemokine RANTES in rat glomerular endothelial cells. Role of the angiotensin type 2 receptor. J. Clin. Invest. 100:1047-1058.

8. Andrews, B.S., et al. 1978. Spontaneous murine lupus-like syndromes. Clinical and immunopathological manifestations in several strains. J. Exp. Med. 148:1198-1215.

9. Theofilopoulos, A.N., and Dixon, F.J. 1981. Etiopathogenesis of murine SLE. Immunol. Rev. 55:179-216.

10. De Albuquerque, D.A., et al. 2004. An ACE inhibitor reduces Th2 cytokines and TGF-beta 1 and TGF-beta2 isoforms in murine lupus nephritis. Kidney Int. 65:846-859.

11. Perez De Lema, G., et al. 2003. Angiotensin inhibition reduces glomerular damage and renal chemokine expression in MRL/lpr mice. J. Pharmacol. Exp. Ther. 307:275-281.

12. Prkacin, I., Novak, B., Sertic, J., and Mrzljak, A.
2001. Angiotensin-converting enzyme gene polymorphism in patients with systemic lupus. Acta Med. Croatica. 55:73-76.

13. Sato, H., et al. 1998. Association of an insertion polymorphism of angiotensin-converting enzyme gene with the activity of systemic lupus erythematosus. Lupus. 7:530-534.

14. Kaufman, K.M., et al. 2001. Linkage analysis of angiotensin-converting enzyme (ACE) insertion/ deletion polymorphism and systemic lupus erythematosus. Mol. Cell. Endocrinol. 177:81-85.

15. Herlitz, H., Edeno, C., Mulec, H., Westberg, G., and Aurell, M. 1984. Captopril treatment of hypertension and renal failure in systemic lupus erythematosus. Nephron. 38:253-256.

16. Spurney, R.F., Ruiz, P., Pisetsky, D.S., and Coffman, T.M. 1991. Enhanced renal leukotriene production in murine lupus: role of lipoxygenase metabolites. Kidney Int. 39:95-102.

17. Crowley, S.D., et al. 2008. Stimulation of lymphocyte responses by angiotensin II promotes kidney injury in hypertension. Am. J. Physiol. Renal Physiol. 295:F515-F524.

18. Chan, R.W., et al. 2004. Expression of chemokine and fibrosing factor messenger RNA in the urinary sediment of patients with lupus nephritis. Arthritis Rheum. 50:2882-2890.

19. Wolf, G. 1998. Link between angiotensin II and TGF-beta in the kidney. Miner. Electrolyte Metab. 24:174-180.

20. Kagami, S., Border, W.A., Miller, D.E., and Noble, N.A. 1994. Angiotensin II stimulates extracellular matrix protein synthesis through induction of transforming growth factor-beta expression in rat glomerular mesangial cells. J. Clin. Invest. 93:2431-2437.

21. Weinberg, J.B., et al. 1994. The role of nitric oxide in the pathogenesis of spontaneous murine autoimmune disease: increased nitric oxide production and nitric oxide synthase expression in MRL-lpr/ lpr mice, and reduction of spontaneous glomerulonephritis and arthritis by orally administered NGmonomethyl-L-arginine. J. Exp. Med. 179:651-660.

22. Theofilopoulos, A., et al. 1985. Association of lpr gene with graft-vs.-host disease-like syndrome.
J. Exp. Med. 162:1-18.

23. Allen, R.D., Marshall, J.D., Roths, J.B., and Sidman, C.L. 1990. Bone marrow transplantation from mutant lpr/lpr mice. Functional abnormalities rather than alloantigenic differences appear to determine the development of a graft-vs.-host-like syndrome. Eur. J. Immunol. 20:2057-2066.

24. Sugaya, T., et al. 1995. Angiotensin II type 1a receptor-deficient mice with hypotension and hyperreninemia. J. Biol. Chem. 270:18719-18722.

25. Oliverio, M.I., et al. 1998. Renal growth and development in mice lacking AT1A receptors for angiotensin II. Am. J. Physiol. 274:F43-F50.

26. Cervenka, L., Mitchell, K.D., Oliverio, M.I., Coffman, T.M., and Navar, L.G. 1999. Renal function in the AT1A receptor knockout mouse during normal and volume-expanded conditions. Kidney Int. 56:1855-1862.

27. Prieto-Carrasquero, M.C., et al. 2004. Enhancement of collecting duct renin in angiotensin II-dependent hypertensive rats. Hypertension. 44:223-229.

28. Oliverio, M.I., Best, C.F., Smithies, O., and Coffman, T.M. 2000. Regulation of sodium balance and blood pressure by the AT $(1 \mathrm{~A})$ receptor for angiotensin II. Hypertension. 35:550-554.

29. Crowley, S.D., et al. 2005. Distinct roles for the kidney and systemic tissues in blood pressure regulation by the renin-angiotensin system. J. Clin. Invest. 115:1092-1099.

30. Harrison-Bernard, L.M., Cook, A.K., Oliverio, M.I., and Coffman, T.M. 2003. Renal segmental microvascular responses to ANG II in AT1A receptor null mice. Am. J. Physiol. Renal Physiol. 284:F538-F545.

31. Bouby, N., et al. 1997. Expression of type 1 angiotensin II receptor subtypes and angiotensin IIinduced calcium mobilization along the rat nephron. J. Am. Soc. Nephrol. 8:1658-1667.

32. Harrison-Bernard, L.M., Monjure, C.J., and Bivona, B.J. 2006. Efferent arterioles exclusively express the subtype $1 \mathrm{~A}$ angiotensin receptor: functional insights from genetic mouse models. Am. J. Physiol. Renal Physiol. 290:F1177-F1186.

33. Barisoni, L., Bruggeman, L.A., Mundel, P., D’Agati, V.D., and Klotman, P.E. 2000. HIV-1 induces renal 
epithelial dedifferentiation in a transgenic model of HIV-associated nephropathy. Kidney Int. 58:173-181.

34. Barisoni, L., Madaio, M.P., Eraso, M., Gasser, D.L., and Nelson, P.J. 2005. The $\mathrm{kd} / \mathrm{kd}$ mouse is a model of collapsing glomerulopathy. J. Am. Soc. Nephrol. 16:2847-2851.

35. Dahlof, B., et al. 2002. Cardiovascular morbidity and mortality in the Losartan Intervention For Endpoint reduction in hypertension study (LIFE): a randomised trial against atenolol. Lancet. 359:995-1003.

36. [No authors listed]. 1987. Effects of enalapril on mortality in severe congestive heart failure. Results of the Cooperative North Scandinavian Enalapril Survival Study (CONSENSUS). The CONSENSUS Trial Study Group. N. Engl. J. Med. 316:1429-1435.

37. Brenner, B.M., et al. 2001. Effects of losartan on renal and cardiovascular outcomes in patients with type 2 diabetes and nephropathy. N. Engl. J. Med. 345:861-869.

38. Crowley, S.D., et al. 2006. Angiotensin II causes hypertension and cardiac hypertrophy through its receptors in the kidney. Proc. Natl. Acad. Sci. U. S. A 103:17985-17990.

39. Ruiz-Ortega, M., et al. 1998. Angiotensin II participates in mononuclear cell recruitment in experimental immune complex nephritis through nuclear factor-kappa B activation and monocyte chemoattractant protein-1 synthesis. J. Immunol. 161:430-439

40. Muller, D.N., et al. 2002. Immunosuppressive treatment protects against angiotensin II-induced renal damage. Am. J. Pathol. 161:1679-1693.

41. Guzik, T.J., et al. 2007. Role of the T cell in the genesis of angiotensin II induced hypertension and vascular dysfunction. J. Exp. Med. 204:2449-2460.

42. Amuchastegui, S.C., et al. 1998. Chronic allograft nephropathy in the rat is improved by angiotensin II receptor blockade but not by calcium channel antagonism. J. Am. Soc. Nephrol. 9:1948-1955.

43. Herlitz, H., Tarkowski, A., Svalander, C., Volkmann, R., and Westberg, G. 1988. Beneficial effect of captopril on systemic lupus erythematosus-like disease in MRL lpr/lpr mice. Int. Arch. Allergy Appl. Immunol. 85:272-277.

44. Crowley, S.D., Tharaux, P.L., Audoly, L.P., and Coffman, T.M. 2004. Exploring type I angiotensin (AT1) receptor functions through gene targeting. Acta Physiol. Scand. 181:561-570.

45. Blantz, R.C., Konnen, K.S., and Tucker, B.J. 1976. Angiotensin II effects upon the glomerular microcirculation and ultrafiltration coefficient of the rat. J. Clin. Invest. 57:419-434.

46. Zatz, R., et al. 1986. Prevention of diabetic glomerulopathy by pharmacological amelioration of glomerular capillary hypertension. J. Clin. Invest. 77:1925-1930

47. Anderson, S., Meyer, T.W., Rennke, H.G., and Brenner, B.M. 1985. Control of glomerular hypertension limits glomerular injury in rats with reduced renal mass. J. Clin. Invest. 76:612-619.

48. Kim, J.M., et al. 2003. CD2-associated protein haploinsufficiency is linked to glomerular disease susceptibility. Science. 300:1298-1300.

49. Kaplan, J.M., et al. 2000. Mutations in ACTN4, encoding alpha-actinin- 4 , cause familial focal segmental glomerulosclerosis. Nat. Genet. 24:251-256.

50. Winn, M.P., et al. 2005. A mutation in the TRPC6 cation channel causes familial focal segmental glomerulosclerosis. Science. 308:1801-1804.

51. Macconi, D., et al. 2000. Effect of angiotensinconverting enzyme inhibition on glomerular basement membrane permeability and distribution of zonula occludens-1 in MWF rats. J. Am. Soc. Nephrol. 11:477-489.

52. Mifsud, S.A., et al. 2001. Podocyte foot process broadening in experimental diabetic nephropathy: amelioration with renin-angiotensin blockade. Diabetologia. 44:878-882.

53. Sharma, M., Sharma, R., Greene, A.S., McCarthy, E.T., and Savin, V.J. 1998. Documentation of angiotensin II receptors in glomerular epithelial cells. Am. J. Physiol. 274:F623-F627.

54. Durvasula, R.V., et al. 2004. Activation of a local tissue angiotensin system in podocytes by mechanical strain. Kidney Int. 65:30-39.

55. Masutani, K., et al. 2001. Predominance of Th1 immune response in diffuse proliferative lupus nephritis. Arthritis Rheum. 44:2097-2106.

56. Peng, S.L., Moslehi, J., and Craft, J. 1997. Roles of interferon-gamma and interleukin-4 in murine lupus. J. Clin. Invest. 99:1936-1946.

57. Takahashi, S., et al. 1996. Imbalance towards Th1 predominance is associated with acceleration of lupus-like autoimmune syndrome in MRL mice. J. Clin. Invest. 97:1597-1604.

58. Balomenos, D., Rumold, R., and Theofilopoulos, A.N. 1998. Interferon-gamma is Required for Lupus-like Disease and Lymphoaccumulation in MRL-lpr Mice. J. Clin. Invest. 101:364-371.

59. Haas, C., Ryffel, B., and Le Hir, M. 1997. IFNgamma is essential for the development of autoimmune glomerulonephritis in MRL/Ipr mice. J. Immunol. 158:5484-5491.

60. Carvalho-Pinto, C.E., et al. 2002. Autocrine production of IFN-gamma by macrophages controls their recruitment to kidney and the development of glomerulonephritis in MRL/lpr mice. J. Immunol. 169:1058-1067.

61. Border, W.A., and Noble, N.A. 1998. Interactions of transforming growth factor-beta and angiotensin II in renal fibrosis. Hypertension. 31:181-188.

62. MacKay, K., et al. 1989. Transforming growth factor-beta. Murine glomerular receptors and responses of isolated glomerular cells. J. Clin. Invest. 83:1160-1167.

63. Sun, Y., Zhang, J., Zhang, J.Q., and Ramires, F.J. 2000. Local angiotensin II and transforming growth factor-beta 1 in renal fibrosis of rats. Hypertension. 35:1078-1084.

64. Goulet, J.L., et al. 1999. Deficiency of 5-lipoxygenase abolishes sex-related survival differences in MRL-lpr/lpr mice. J. Immunol. 163:359-366.

65. Hylkema, M.N., et al. 1994. Clinical evaluation of a modified ELISA, using photobiotinylated DNA, for the detection of anti-DNA antibodies. J. Immunol. Methods. 170:93-102.

66. Ito, M.R., Ono, M., Itoh, J., and Nose, M. 2003. Bone marrow cell transfer of autoimmune diseases in a MRL strain of mice with a deficit in functional Fas ligand: dissociation of arteritis from glomerulonephritis. Pathol. Int. 53:518-524.

67. Chen, B.J., Cui, X., Sempowski, G.D., Domen, J., and Chao, N.J. 2004. Hematopoietic stem cell dose correlates with the speed of immune reconstitution after stem cell transplantation. Blood. 103:4344-4352.

68. Mickisch, G., et al. 1992. Transplantation of bone marrow cells from transgenic mice expressing the human MDR1 gene results in long-term protection against the myelosuppressive effect of chemotherapy in mice. Blood. 79:1087-1093.

69. Thomas, D.W., et al. 2003. Proinflammatory actions of thromboxane receptors to enhance cellular immune responses. J. Immunol. 171:6389-6395.

70. Spurney, R.F., et al. 1994. Leukotrienes in renal transplant rejection in rats. Distinct roles for leukotriene B4 and peptidoleukotrienes in the pathogenesis of allograft injury. J. Immunol. 152:867-876.

71. Kim, H.S., Lee, G., John, S.W., Maeda, N., and Smithies, O. 2002. Molecular phenotyping for analyzing subtle genetic effects in mice: application to an angiotensinogen gene titration. Proc. Natl. Acad. Sci. U. S. A. 99:4602-4607.

72. Cui, S., Li, C., Ema, M., Weinstein, J., and Quaggin, S.E. 2005. Rapid isolation of glomeruli coupled with gene expression profiling identifies downstream targets in Pod1 knockout mice. J. Am. Soc. Nephrol. 16:3247-3255.

73. Eremina, V., et al. 2006. Vascular endothelial growth factor a signaling in the podocyte-endothelial compartment is required for mesangial cell migration and survival. J. Am. Soc. Nephrol. 17:724-735.

74. MacKay, K., et al. 1988. Glomerular epithelial, mesangial, and endothelial cell lines from transgenic mice. Kidney Int. 33:677-684. 